\title{
Aktuální zpráva ke kontaktům dítěte v pěstounské péči s biologickou rodinou
}

\author{
Natalie Jeníčková, Irena Sobotková, Jaroslav Šturma
}

V prosinci loňského roku obdržely orgány sociálně-právní ochrany dětí a nestátní neziskové organizace pověřené $\mathrm{k}$ výkonu sociálně-právní ochrany dětí „Doporučení zástupkyně veřejného ochránce práv ke kontaktům dítěte $\mathrm{v}$ pěstounské péči nejen s rodiči“. Toto doporučení vyvolalo ihned živý ohlas pěstounů, doprovázejících organizací a některých orgánů sociálně-právní ochrany dětí. Aktivní členové Sekce pro náhradní rodinnou péči při Českomoravské psychologické společnosti zveřejnili ke zmíněnému dokumentu stanovisko, v němž upozorňují na opomíjení zájmu dítěte a apelují na zohlednění odborných psychologických poznatků i zkušeností z praxe. Plný text stanoviska zde přetiskujeme. Rádi bychom, aby i na stránkách E-psychologie toto aktuální téma upoutalo zájem odborníků a podnítilo další diskusi.

Stanovisko Sekce pro náhradní rodinnou péči při Českomoravské psychologické společnosti k návrhu Mgr. Moniky Šimůnkové „Doporučení zástupkyně veřejného ochránce práv ke kontaktům dítěte $\mathrm{v}$ pěstounské péči nejen $\mathrm{s}$ rodiči““"1

(ze dne 18. 12. 2020)

Členové Sekce pro náhradní rodinnou péči při ČMPS se seznámili s uvedeným materiálem (dále jen „návrh“) a považují za nezbytné na něj reagovat. Návrh vychází pouze z hlediska práva. Každý dílčí pohled na složitou problematiku je však sám o sobě jednostranný. Dobrá praxe v náhradní rodinné péči vyžaduje mezioborovou diskusi a spolupráci, nebot' jde o nejslabší a nejzranitelnější - o děti.

Návrh vůbec nezohledňuje psychologické aspekty, zejména poznatky z vývojové psychologie o psychickém vývoji dítěte a jeho psychických potřebách. Rovněž nebere v úvahu časté zkušenosti pěstounů, psychologů a sociálních pracovníků s tím, že necitlivě realizované kontakty mají zřetelný negativní dopad na děti svěřené do pěstounské péče. Níže uvedenými argumenty upozorňujeme na jeho problematické vyznění.

\section{Práva a povinnosti}

V návrhu je tvrdě prosazováno právo rodiče, nikoli však zájem dítěte. Není ani jednou zmíněno, že dítě má právo, nikoliv však povinnost styku s biologickým rodičem.

Zákonná povinnost rodiče řádně pečovat o dítě, kterou rodič svým chováním a stylem života porušuje, je opomíjena. Z logiky věci by se měla především řešit zodpovědnost rodiče za neplnění jeho povinností, a poté by měl rodič prokázat, že je v zájmu dítěte, aby se s ním nadále stýkal.

\footnotetext{
${ }^{1}$ Odkaz na Doporučení (18. 12. 2020)
} 


\section{Zájem dítěte}

V návrhu je používán pojem ,zájem dítěte“, ačkoli důsledná aplikace návrhu by v zájmu dětí nebyla. Z hlediska dětské psychologie je „zájmem dítěte“ jednoznačně míněno to, aby byly spolehlivě uspokojovány veškeré potřeby dítěte. Tedy nejen základní biologické potřeby (výživa, ochrana, spánek, hygiena atd.) a specifické vývojové potřeby, ale i základní psychické potřeby dítěte. Jedná se o životně důležité potřeby dítěte psychologické a sociální povahy, se kterými pracuje moderní vývojová psychologie. Jde o (1) potřebu dostatečných podnětů pro rozvoj dítěte, (2) potřebu stálého a srozumitelného prostředí, (3) potřebu bezpečných citových a sociálních vztahů, (4) potřebu bezvýhradného přijetí a akceptace důležitými lidmi a (5) potřebu sdílené budoucnosti s rodinou.

Z psychologického hlediska platí, že pokud není zájem biologických rodičů a dítěte v souladu, má přednost zájem dítěte. Často jde o situace, kdy rodiče si kontakt nárokují, ale dítěti by uškodil. Běžně jde o prŕpady, kdy rodiče dítě dlouhodobě zanedbávali, mravně ohrožovali, vystavovali domácímu násilí, projevům těžké závislosti na drogách atd.

Náš přední a ve světě uznávaný dětský psycholog prof. Zdeněk Matějček na základě dlouholeté práce v oblasti náhradní rodinné péče publikoval tuto zásadu: „Je nepř́ípustné, aby se dítě stalo jen prostředkem k uspokojování potřeb dospělých, aniž by současně, a to přednostně, byly uspokojovány potřeby jeho“. Psychologové sdružení v Sekci pro NRP při ČMPS se k jeho odkazu plně hlásí.

\section{Kvalita biologických rodin}

Návrh nereflektuje kvalitu biologických rodin, z nichž jsou děti svěřovány do pěstounské péče. Rodinné prostředí bývá krajně rizikové, dysfunkční, s výskytem různé sociální patologie, ohrožující zdravý vývoj a někdy i život dítěte. V těchto rodinách je typický výskyt závislostí rodičů na alkoholu a jiných návykových látkách, dále domácí násilí, trvalý nezájem o děti, nezaměstnanost, dluhy atd.

Podle návrhu je přitom OSPOD ,povinen po odebrání dítěte $\mathrm{z}$ péče rodičů s rodinou dále spolupracovat $s$ cílem navrácení dítěte zpět do rodiny a rodiče a dítě po jejich rozdělení aktivně podporovat v jejich brzkém kontaktu“.

Děti nejsou odebírány z biologických rodin z banálních důvodů. Ostatně to ani zákon neumožňuje. Hlavní deklarované důvody odebrání dítěte z rodiny jsou sice nevhodné sociální podmínky, prríp. nemoc či neschopnost rodičů, ale ve skutečnosti jde téměř vždy o kombinaci s těžkým zanedbáváním dítěte, často se závislostmi rodičů, domácím násilím či dokonce týráním či zneužíváním dítěte. Je rovněž známo, že sanace těchto rodin je velmi obtížná a často nemožná. Veškerá podpora a pomoc rodičům se často míjí účinkem.

V návrhu je uvedeno, že rodiče jsou po odebrání dítěte „napjatí a vystresovaní“ a potřebují ohledně kontaktů jistotu; dohoda o kontaktech by měla být učiněna ,V řádu hodin či maximálně dnư“. Tento př́stup je zavádějící, nebot' rodiče jsou zde stavěni do role oběti. Z psychologického i etického hlediska je však v prvé řadě nutno pomoci dítěti a jednat $v$ jeho zájmu.

$\mathrm{Na}$ problematiku kontaktů $\mathrm{v}$ oblasti NRP nelze nahlížet stejně jako na kontakty rodičů a dětí v rozvodových případech. Je zde zásadní rozdíl: vztahy odebraného dítěte a rodičů jsou většinou problematické či vážným způsobem narušené. Při úvaze o kontaktech v oblasti NRP je tedy naprosto nutné brát v úvahu kvalitu rodin, vztahy v rodině a rodičovské kompetence. 


\section{Nadřazování pokrevních vazeb}

Návrh je založen na přesvědčení, že vlastní rodina a pokrevní vazby nemohou být plnohodnotně nahrazeny vztahy nepokrevními. Je pravda, že pro zdárný vývoj dítěte je ideálním prostředím vlastní rodina, ovšem tehdy, pokud řádně plní své funkce vůči dítěti.

Zmíněný prof. Matějček se k této věci jasně vyjádřil ve svých statích takto: psychologické rodičovství je plnohodnotné a v pravém slova smyslu zachraňující pro děti, které byly v biologických rodinách ohroženy. Předpoklad o nenahraditelnosti pokrevních vztahů označil za mýtus, nebot' nikdy nebyl vědecky potvrzen. Naopak, výzkum i zkušenosti z praxe dokládají, že dítě vnímá jako pravé rodiče ty osoby, které se o něj skutečně rodičovsky, tj. nepřetržitě, spolehlivě a s láskou starají.

Právě přeceňování a nadřazování pokrevních vazeb vede $\mathrm{k}$ silnému tlaku na realizaci kontaktů dětí s biologickými rodiči. Zkušení psychologové, sociální pracovníci a pěstouni ale vědí, že tyto kontakty často narušují psychickou stabilitu dítěte a jeho výchovu, dokonce rovnováhu celé pěstounské rodiny. Je nutné klást si rovněž otázku, k čemu mají kontakty do budoucna vést, jaká je perspektiva vztahu mezi rodiči a dítětem.

Kontakty rodičů s dítětem nelze organizovat jen na základě přání rodičů. Je potřeba uvažovat v širším kontextu a mít stále na paměti, že právě rodiče závažným způsobem ohrozili a poškodili vývoj dítěte (tak tomu je v drtivé většině prrípadů, vyjímaje rodiče, kteří nemohou pečovat o dítě napřr. kvůli zdravotnímu stavu).

\section{Vývojově-psychologické poznatky}

Návrh ignoruje poznatky z vývojové psychologie. Jde o to, že dítě má v každém období specifické vývojové potřeby, které je nutno respektovat, i když do zákona to promítnuto není. Jako př́íklad je možno uvést období batolete, kdy se začíná utvářet osobnost a osobní identita dítěte. Dítě potřebuje jasně vnímat, kdo je jeho rodina, kam patří, s kým má společnou vztahovou perspektivu. Až poté, co v pěstounské rodině naváže bezpečné a hluboké citové vztahy, je možné nějakou formu kontaktu zvažovat. Ani dítě v předškolním věku a starší však většinou nezvládne tzv. konflikt dvojí loajality, tedy stav, kdy je ,mezi rodinami“.

Praxe ukazuje, že $\mathrm{v}$ době adaptace na novou rodinu bývá kontakt s biologickými rodiči pro dítě zvýšeně ohrožující. I pozdější občasné kontakty mohou být pro dítě traumatizující, vyvolávají opakovaně emoční zmatek a nadměrný stres. To mívá jak bezprostřední negativní dopady na prožívání a chování dítěte (úzkost, věkový regres, agresivita aj.), tak dlouhodobé následky, hlavně v sociálním a citovém vývoji.

Už několik let praxe ukazuje, že tvrdě prosazované kontakty, které se řídí jen ustanovením zákona, jsou pro děti škodlivé. To dokládá zahraniční i naše odborná literatura. Jedná se o články a knihy psychologů, sociálních pracovníků a psychiatrů, jejichž stručný výběr uvádíme na konci tohoto stanoviska. Další zdroje lze dohledat.

Z výzkumů a praxe také vyplývá, že kontakt dítěte v pěstounské péči s jeho biologickými rodiči není nutný nebo dobrý „sám o sobě“, nýbrž musí mít vždy jasný a konkrétní přínos pro dítě. Pokud není reálný předpoklad, že by se dítě mohlo do rodiny vrátit, mnozí zahraniční odborníci vůbec kontakty nedoporučují, nebot' dítě je vystaveno většinou neprríznivému prostředí, životnímu stylu a hodnotám, které jsou v rozporu s tím, k čemu dítě vychovávají a vedou pěstouni (poctivost, pracovitost atd.). 


\section{Identita dítěte}

Jeden z častých argumentů pro realizaci kontaktů je identita dítěte. Dítě má samozřejmě právo na pravdivé informace o svých rodičích, to však nelze zaměňovat za nutnost kontaktu s rodiči v príípadech, kdy je kontakt vysoce rizikový. Praxe svědčí o tom, že takové kontakty bohužel mnohdy probíhají, aniž by bylo vydáno soudní rozhodnutí o omezení či zákazu kontaktu, na které se návrh odvolává jako na pojistku proti poškozování dětí.

Výzkumy jasně ukázaly, že dítě v dlouhodobé pěstounské péči si vytváří pozitivní osobní identitu na základě přijetí a funkčních vztahů v pěstounské rodině, kde mohlo bezpečně citově zakotvit, nikoli na základě kontaktu s biologickou rodinou či na základě informací o ní.

\section{Pěstouni, soudy, OSPOD, doprovázející organizace}

V návrhu je uvedeno, že: „Na podmínkách a četnosti styku dítěte s rodiči i dalšími osobami by se měli primárně dohodnout pěstouni a rodiče. Pokud se tyto strany nemohou dohodnout, jedině soud může o podmínkách a četnosti styku rozhodnout.“ Taková praxe není reálná. Nelze požadovat, aby se pěstouni dohodli s rodiči, protože spolupráce s nimi je problematická a extrémně náročná i pro sociální pracovníky. Pěstouny by to neúměrně zatížilo. A soudy jsou, jak známo, trvale přetížené. Pokud by měly rozhodovat o každém př́ípadu, kdy by se rodiče a pěstouni nedohodli, jejich práce by se ještě více zpomalila.

Praxe doporučovaná $\mathrm{v}$ návrhu by do budoucna rozhodně nepřispěla k nacházení obětavých dlouhodobých pěstounů, kterých je naprostý nedostatek. Už nyní pro ně kontakty představují velký problém. Narušují totiž nejen psychickou stabilitu svěřeného dítěte, ale i atmosféru, př́ípadně vztahy v pěstounské rodině.

Pracovníci OSPODů a doprovázejících organizací by měli mít dostatek odborných znalostí z dětské psychologie a spolupracovat především v zájmu dítěte, nikoli vyvíjet tlak na kontakty ze strachu před stížnostmi biologických rodičů.

\section{V neposlední řadě ...}

... stojí za zmínku, že současný Diagnostický a statistický manuál duševních poruch (DSM 5) nově zařazuje zanedbávání a neuspokojování citových potřeb dítěte a střídání pečujících osob k prríčinám poruch souvisejících s traumatem a stresem. Proto není možné, aby organizace pověřené výkonem sociálně-právní ochrany dětí daly přednost přání rodičů, kteří se dožadují kontaktu, před ochranou zdárného vývoje dítěte a odbornými poznatky.

\section{Závěr}

V rodinách stále řešíme negativní dopady tvrdého prosazování kontaktů dítěte s biologickou rodinou. Tyto kontakty často vedou k emočnímu zmatku, opakovanému zklamání, celkové destabilizaci psychického vývoje dítěte, k zesílení poruch chování, někdy i ke znejistění jeho pozice v pěstounské rodině. Zákon je zákon, ale je nutné zohlednit i odborná hlediska, vývoj a psychické potřeby dítěte, praktické zkušenosti a výzkumná zjištění. Dítě samo je nezralé, není schopno posoudit všechna rizika a souvislosti. Rovněž biologický rodič, jemuž bylo dítě ze závažných důvodů odebráno, nemůže být 
považován za toho, kdo správně posoudí, co je dítěti ku prospěchu a co ne. Právě systém sociálněprávní ochrany by měl zájem dítěte chránit, a ne slepě prosazovat ustanovení zákona. Ačkoliv návrh Mgr. Šimůnkové má přispět k dodržování práv dětí, jak autorka uvádí, jeho realizace bez přihlédnutí k psychologickým aspektům by de facto znamenala poškozování dětí. Apelujeme tedy na to, aby všichni zúčastnění postupovali maximálně citlivě a s respektem $\mathrm{k}$ psychickým potřebám dítěte, zejména k potřebě citového bezpečí a jistoty. Přivítáme širší odbornou diskusi na toto téma.

1. 2. 2021

Toto Stanovisko bylo odesláno na Úřad ombudsmana 2. února 2021. Dne 4. března 2021 obdržela Sekce pro NRP při ČMPS odpověd'. Její znění je dostupné na tomto odkazu. Zástupci Sekce pro NRP při ČMPS plánují setkání s Mgr. Šimůnkovou a jednají v této věci s pracovníky Ministerstva práce a sociálních věcí ČR.

Zdroje:

Bělská, S., Jeníčková, N., Sobotková, I., a kol. (2019). Pěstounská péče na přechodnou dobu v současné praxi náhradní rodinné péče: výsledky průzkumu psychologů Sekce pro náhradní rodinnou péči. E-psychologie, 13(2), 58-62. Dostupné na https://doi.org/10.29364/epsy.344

Bowlby, J. (2010). Vazba. Portál.

Bowlby, J. (2012). Odloučení. Portál.

Bowlby, J. (2013). Ztráta. Portál.

Goodyer, A. (2011). Child-centred foster care. A rights-based model for practice. Jessica Kingsley Publishers.

Neil, E., Beek, M., Schofield, G. (2003). Thinking about and managing contact in permanent placements: the differences and similarities between adoptive parents and foster carers. Clinical Child Psychology and Psychiatry, 8(3), 401-418.

Neil, E., Howe, D. (Eds.). (2004). Contact in adoption and permanent foster care. Research, theory and practice. British Association for Adoption and Fostering.

Macaskill, C. (2002). Safe contact? Children in permanent placement and contact with their birth relatives. Russell House Publishing.

Matějček, Z. (2004). Příprava koncepce péče o děti bez vlastního rodinného zázemí.

[Nepublikovaný rukopis].

Matějček, Z. (2004). Psychologické eseje (z konce kariéry). Karolinum.

Matějček, Z. (2004). Základni teze k péči o dítě (nejen) do tři let věku bez rodinného zázemí $z$ hlediska dětské psychologie. [Nepublikovaný rukopis].

Matějček, Z. (2010). Co děti nejvíc potřebují. Portál.

Sinclair, I. (2010). What makes for effective foster care: Some issues. In E. Fernandez, R. P. Barth (Eds.), How does foster care work? International evidence on outcomes (189-204). Jessica Kingsley Publishers. 
Sobotková, I. (2010). Biologické rodiny dětí, které jsou navrhovány do náhradní rodinné péče. Epsychologie, 4(1), 51-57. Dostupné na https://e-psycholog.eu/pdf/sobotkova.pdf

Sobotková, I., Očenášková, V. (2013). Pěstounská péče očima dospělých, kteři v ní vyrostli: trendy vs. zkušenosti. Univerzita Palackého.

Stott, T. (2012). Placement instability and risky behaviors of youth aging out of foster care. Child and Adolescent Social Work Journal, 29(1), 61-83.

Taplin, S. (2005). Is all contact between children in care and their birth parents ,,good" contact? Centre for Parenting \& Research.

Vítková, A. a kol. (2019). Kontakty dětí v pěstounské péči s biologickou rodinou - úskali a rizika. Přiručka pro odborniky působící v oblasti SPOD. Sdružení pěstounských rodin.

\section{O autorech}

Mgr. Natalie Jeníčková působí jako psycholožka a terapeutka v Rodinném centru Zdeňka Matějčka při DC Paprsek.

Kontaktní údaje:

Adresa: DC Paprsek -Dětské centrum Zdeňka Matějčka, Svépravická 701, 19000 Praha 9

E-mail: natalie.jenickova@dcpaprsek.org

Doc. PhDr. Irena Sobotková, CSc. působí jako psycholožka ve Sdružení pěstounských rodin, z.s.

Kontaktní údaje:

Adresa: Anenská 10, 60200 Brno

E-mail: sobotkova@pestouni.cz

PhDr. Jaroslav Šturma působí jako psycholog v Rodinném centru Zdeňka Matějčka při DC Paprsek. Kontaktní údaje:

Adresa: DC Paprsek -Dětské centrum Zdeňka Matějčka, Svépravická 701, 19000 Praha 9

E-mail: Jaroslav.sturma@gmail.com

Jeníčková, N., Sobotková, I., \& Šturma, J. (2021). Aktuální zpráva ke kontaktům dítěte v pěstounské péči s biologickou rodinou. E-psychologie, 15(1), 97-102. https://doi.org/10.29364/epsy.397 